\title{
STRATEGI MENINGKATKAN KUNJUNGAN PADA LAYANAN ANAK DI DINAS PERPUSTAKAAN DAN KEARSIPAN KABUPATEN SIJUNJUNG
}

\author{
Falian Sumitra ${ }^{1} \&$ Gustina Erlianti $^{2}$ \\ ${ }^{1}$ Universitas Negeri Padang \\ ${ }^{2}$ Universitas Negeri Padang \\ Correspondence email: falians040@gmail.com
}

\begin{abstract}
This study discusses the librarian's strategy in increasing the percentage of visits to children's services at the Library and Archives Office of Sijunjung Regency. The purpose of this research is to find out how the strategies librarians use in increasing visits to children's services and what are the obstacles faced by librarians in increasing visits to children's services at the Library and Archives Office of Sijunjung Regency. The research method used is descriptive with a qualitative approach. Data collection techniques used were observation, interviews and literature. The results of this study are the strategies employed by librarians in increasing the percentage of visits to first-child services, doing competitions, be it coloring competitions, story competitions, and painting competitions. Second, doing storytelling and tutoring activities. Third, attracting children with a mobile library. As for the obstacles faced by librarians, namely the lack of facilities or facilities and infrastructure in children's services, limited labor and librarians, as well as views from the community.
\end{abstract}

Keywords: Library, Children's services, Storytelling

\begin{abstract}
Abstrak
Penelitian ini membahas mengenai strategi pustakawan dalam meningkatkan persentase kunjungan terhadap layanan anak di Dinas Perpustakaan dan Kearsipan Kabupaten Sijunjung. Tujuan penelitian ini untuk mengetahui bagaimana strategi yang dilakukan pustakawan dalam meningkatkan kunjungan di layanan anak dan apa saja kendala yang dihadapi oleh pustakawan dalam meningkatkan kunjungan di layanan anak di Dinas Perpustakaan dan Kearsipan Kabupaten Sijunjung. Metode penelitian yang digunakan adalah deskriptif dengan pendekatan kualitatif. Teknik pengumpulan data yang digunakan berupa observasi, wawancara dan kepustakaan. Hasil dari penelitian ini yaitu strategi yang dilakukan oleh pustakawan dalam meningkatkan persentase kunjungan di
\end{abstract}


layanan anak pertama, melakukan lomba baik itu lomba mewarnai, lomba bercerita, dan lomba melukis. Kedua, melakukan kegiatan storytelling dan bimbingan belajar. Ketiga, menarik pemustaka anak dengan perpustakaan keliling. Adapun hambatan yang dihadapi oleh pustakawan yaitu kurangnya fasilitas atau sarana dan prasarana di layanan anak, keterbatasan tenaga kerja dan pustakawan, serta padangan dari masyarakat.

Kata Kunci: Perpustakaan, Layanan anak, Storytelling 


\section{A. Pendahuluan}

Dalam bahasa Inggris perpustakaan dikenal dengan istilah library. Istilah ini berasal dari kata latin yaitu liber atau libri artinya buku. Pengertian perpustakaan lebih umum menurut (Sulistyo-Basuki, 1993) adalah sebuah ruangan, bagian sebuah gedung, ataupun gedung itu sendiri yang digunakan untuk menyimpan buku dan terbitan lainya yang biasanya di simpan menurut tata susunan tertentu untuk digunakan pembaca, bukan untuk dijual. Perpustakaan merupakan suatu gedung yang berisikan informasi yang dibutuhkan oleh pemustaka. Informasi tersebut dapat berupa buku, jurnal, peta, buku panduan, petunjuk khusus, kumpulan indeks, kumpulan abstrak, dan lain-lain yang dibutuhkan oleh pemustaka dalam pemenuhan informasi serta koleksi-koleksi tersebut dapat dipinjam oleh pemustaka ataupun dibaca ditempat.

Menurut (Sjahrijal-Pamuntjak, 2000) perpustakaan umum adalah perpustakan yang menghimpun koleksi buku, bahan cetakan serta rekaman lain untuk kepentingan masyarakat umum. Perpustakaan umum berdiri sebagai lembaga yang diadakan untuk dan oleh masyarakat. Setiap warga dapat mempergunakan perpustakaan tanpa dibedakan pekerjaan, kedudukan, kebudayaan dan agama. Perpustakaan umum merupakan suatu gedung yang memiliki beragam informasi terkait kebutuhan yang dibutuhkan oleh masyarakat umum baik itu dari koleksi maupun layanan yang disediakan untuk umum.

Dalam menjalankan perannya, perpustakaan umum berkewajiban memberikan layanan kepada masyarakat (pemustaka). Layanan perpustakaan merupakan suatu kegiatan utama sebagai alat ukur keberhasilan suatu perpustakaan. Pelayanan bersifat universal, artinya berlaku secara umum atau terhadap siapa saja yang menginginkannya. Oleh karena itu, pelayanan yang diberikan oleh pustakawan harus maksimal agar perpustakaan tetap eksis dimata pemustaka (Wahyuni, 2015). Layanan yang baik yaitu layanan yang dapat memenuhi kebutuhkan informasi pemustaka dan sebagai tempat rekreasi bagi pemustaka dimana pemustaka senang ketika berkunjung ke perpustakaan. Adapun layanan yang dimaksud yaitu layanan sirkulasi dan layanan anak.

Perpustakaan di Dinas Perpustakaan dan Kearsipan Kabupaten Sijunjung memiliki salah satu layanan yang dapat meningkatkan presentase kunjungan yang disebut dengan layanan perpustakaan keliling dan layanan anak.

Layanan anak merupakan suatu layanan yang terdapat di perpustakaan umum. layanan ini ditujukan kepada anak-anak baik dari koleksi, alat-bermain anak, dan lain-lain. Layanan anak pada perpustakaan umum memiliki peran yang sangat besar 
terhadap peningkatan citra di perpustakaan umum. Namun, banyak dari masyarakat umum belum mengetahui apa itu layanan anak dan kebanyakan dari masyarakat umum masih mengganggap bahwa perpustakaan itu hanyalah sebuah gudang tempat untuk menyimpan berbagai koleksi yang tidak terpakai.

Layanan anak di Dinas Perpustakaan dan Kearsipan Kabupaten Sijunjung merupakan perpustakaan umum di Kabupaten Sijunjung yang memiliki layanan anak. Layanan anak pada perpustakaan ini terletak pada sudut kanan lantai 2 . Namun, pemustaka yang berkunjung ke layanan ini tidak banyak, adapun fasilitas yang terdapat di layanan ini sangat minim, serta pelayanan yang diberikan oleh pustakawan di perpustakaan tidak maksimal terhadap pemustaka yang seharusnya diperhatikan lebih dibandingkan dengan layanan lain.

Oleh karena itu, penulis tetarik untuk meneliti layanan anak di Dinas Perpustakaan dan Kearsipan Kabupaten Sijunjung. Beberapa penelitian yang pernah dilakukan penulis lain terkait topik ini antara lain : penelitian yang dilakukan oleh Suci Lestari dengan judul "Peran Pustakawan dalam Memotivasi Anak Usia Dini Memanfaatkan Layanan Anak di Badan Perpustakaan dan Kearsipan Provinsi Sumatera Barat". Penelitian ini berusaha untuk menggambarkan bagaimana peran pustakawan dalam memotivasi anak usia dini dalam memanfaatkan layanan anak dan kendala yang dihadapi dalam layanan anak serta upaya yang dilakukan untuk mengatasi masalah pada layanan anak di Badan Perpustakaan dan Kearsipan Provinsi Sumatera Barat. Hasil dari penelitian ini berupa deskripsi terhadap layanan anak di Badan Perpustakaan dan Kearsipan Provinsi Sumatera Barat (Lestari \& Nelisa, 2015).

Penelitian kedua yang diteliti oleh Mifathul Rizki dengan judul "Strategi Mendongeng di Dinas Perpustakaan dan Arsip Provinsi Sumatera Utara". Penelitian ini bertujuan untuk menjelaskan bagaimana strategi kegiatan mendongeng pada layanan anak di Dinas Perpustakaan dan Arsip Provinsi Sumatera Utara dan mengetahu apa saja hambatan yang dihadapi dalam kegiatan mendongeng pada pelayanan anak di Dinas Perpustakaan dan Arsip Provinsi Sumatera Utara. Hasil dari penelitian ini mengenai bagaimana kegiatan mendongeng dapat meningkatkan minat baca anak di layanan anak tepatnya di Dinas Perpustakaan dan Arsip Provinsi Sumatera Utara (Rizki, 2019).

Dari kedua penelitian yang sudah dilakukan sebelumnya terdapat persamaan dan perbedaan. Persamaan dari penelitian ini yaitu membahas mengenai layanan yang ada di perpustakaan yaitu layanan anak. Adapun perbedaan dari kedua penelitian ini yaitu penelitian pertama membahas mengenai bagaimana peran dari pustakawan 
dalam memotivasi anak memanfaatkan layanan anak di perpustakaan, sedangkan penelitian kedua membahas mengenai strategi dari kegiatan mendongeng sebagai cara untuk menarik minat baca anak di layanan anak.

Berdasarkan kedua penelitian di atas, membuktikan bahwa penelitian ini belum pernah dilakukan sebelumnya, terutama di daerah Kabupaten Sijunjung. Penelitian ini juga membahas mengenai pendapat dari pegawai perpustakaan mengenai strategi dalam meningkatkan kunjungan di layanan anak di Dinas Perpustakaan dan Kearsipan Kabupaten Sijunjung dimana penelitian ini belum pernah diteliti oleh peneliti sebelumnya, khususnya di Kabupaten Sijunjung. Penelitian ini bisa menjadi acuan bagi instansi lain yang juga memiliki layanan anak di perpustakaannya.

Berdasarkan penjelasan di atas, maka dapat saya rumuskan beberapa masalah yaitu, (1) strategi yang dilakukan pustakawan dalam meningkatkan persentase pengunjung pada layanan anak di Dinas Perpustakaan dan Kearsipan Kabupaten Sijunjung, (2) faktor penghambat yang dihadapi oleh perpustakaan dalam meningkatkan persentase pengunjung pada layanan anak di Dinas Perpustakaan dan Kearsipan Kabupaten Sijunjung.

\section{B. Metodologi Penelitian}

Menurut Arikunto (Cahyaningtyas \& Iriyani, 2015) metode penelitian adalah cara yang digunakan oleh peneliti dalam pengumpulan data penelitiannya. Berdasarkan pengertian tersebut dapat disimpulkan bahwa metode penelitian adalah cara yang digunakan oleh peneliti untuk mengumpulkan data yang diperlukan dalam penelitiannya.

Menurut (Moleong, 2001) pencatatan sumber data melalui wawancara atau pengamatan merupakan hasil gabungan dari kegiatan melihat, mendengar, dan bertanya. Pada penelitian kualitatif, kegiatan kegiatan ini dilakukan secara sadar, terarah dan senantiasa bertujuan memperoleh suatu informasi yang diperlukan.

Berdasarkan penjelasan di atas, maka metode yang digunakan dalam penelitian ini yaitu metode deskriptif dengan pendekatan kualitatif yang mana bertujuan untuk mendeskripsikan fakta akurat yang berkaitan dengan Strategi Pustakawan dalam Meningkatkan Persentase Kunjungan pada Layanan Anak di Dinas Perpustakaan dan Kearsipan Kabupaten Sijunjung. Adapun informasi dalam penelitian ini diperoleh melalui wawancara dengan Bapak rahman, Ibu Yul, dan Kak Ivy. Penelitian ini dilakukan pada September-Oktober 2020. 


\section{Hasil Penelitian}

Strategi yang dilakukan pustakawan dalam meningkatkan persentase pengunjung pada layanan anak di Dinas Perpustakaan dan Kearsipan Kabupaten Sijunjung

\section{Mengadakan lomba}

Lomba yang diadakan yaitu lomba mewarnai tingkat TK, lomba bercerita tingkat SD dan lomba melukis tingkat SLTP. Kegiatan lomba tersebut dilakukan 1 kali setiap tahunnya yaitu pada Februari yang bertepatan dengan hari jadi Kabupaten Sijunjung. Lomba tersebut telah dilaksanakan sejak tahun 2012 sampai sekarang.

Pengadaan lomba sangat membantu perpustakaan dalam hal untuk mengedukasi masyarakat atau orang tua anak agar beranggapan bahwa perpustakaan tidak hanyalah sebuah gudang penyimpanan koleksi saja melainkan juga menyediakan layanan untuk anak yang mana layanan ini dapat digunkanan oleh anak untuk belajar, bermain, dan bersosialisasi. Lomba ini dapat menumbuhkan minat baca pada diri anak dan rasa ketertarikan untuk berkunjung ke perpustakaan khususnya di layanan anak.

\section{Melakukan kegiatan storytelling dan bimbingan belajar}

Pustakawan dan tenaga kerja melakukan suatu kegiatan agar membuat anak menjadi betah ketika berada di perpustakaan. Adapun kegiatan yang dilakukan oleh pustakawan dan tenaga kerja yaitu melakukan storytelling di layanan anak. Storytelling ini dilakukan setiap Senin-Rabu dengan tema yang berbeda-beda. Tema yang dibawakan oleh pustakawan dan tenaga kerja yaitu seperti monyet dan buaya, gagak dan elang, kelinci dan kura-kura, dan lain-lain. Hal ini dilakukan agar anak-anak betah berada di perpustakaan dan memicu minat baca dari anak tersebut sejak dini.

Selain itu, adapun kegiata yang dilakukan oleh pustakawan dan tenaga kerja yaitu seperti melakukan bimbingan belajar bagi anak baik itu seperti bimbingan menggambar, mewarnai, menulis dan bahkan bimbingan membaca bagi anak. Dengan adanya kegiatan ini anak merasa senang dan akan lebih aktif dan kreatif dalam berkreasi. Selain itu orangtua dari anak juga akan merasa tertolong dengan adanya kegiatan ini dikarenakan biasanya orangtua dari anak tersebut memiliki kesibukan yang beragam sehingga tidak dapat membimbing anaknya dengan maksimal dalam hal belajar. 


\section{Menarik pemustaka anak melalui perpustakaan keliling}

Perpustakaan keliling dapat membantu dalam hal meningkatkan kunjungan pemustaka anak di layanan anak. Hal ini dikarenakan dengan adanya perpustakaan keliling yang berkunjung setiap Rabu-Jumat ke berbagai sekolah di Kabupaten Sijunjung. Adapun sekolah yang dikunjungi oleh perpustakaan yaitu seperti TK, SD, dan SMP. Dalam hal ini berarti perpustakaan keliling memiliki peran penting untuk meningkatkan minat baca serta mengajak anak-anak untuk berkunjung ke perpustakaan tepatnya pada layanan anak.

Adapun koleksi yang terdapat di perpustakaan keliling yaitu koleksi anak seperti adanya komik, novel, buku anak seperti mengenal huruf dan angka, pintar mewarnai dan menggambar, buku cerita anak, pantun dan dongeng anak, dll.

\section{Faktor penghambat yang dihadapi oleh perpustakaan dalam meningkatkan persentase pengunjung pada layanan anak di Dinas Perpustakaan dan Kearsipan Kabupaten Sijunjung}

Berdasarkan hasil wawancara penulis dengan narasumber tentang layanan anak di Dinas Perpsustakaan dan Kearsipan Kabupaten Sijunjung. Adapun faktor penghambat yang dihadapi oleh pustakawan dalam meningkatkan persentase pengunjung pada layanan anak di Dinas Perpustakaan dan Kearsipan Kabupaten Sijunjung yaitu: (1) kurangnya fasilitas atau sarana dan prasarana di layanan anak, (2) keterbatasan tenaga kerja dan pustakawan, (3) pandangan masyarakat.

\section{Kurangnya fasilitas atau sarana dan prasarana di layanan anak}

Fasilitias yang dimaksud di layanan anak ini yaitu seperti kurangnya alat-alat untuk bermain anak seperti: puzzle, balok-balok konstruksi, alat-alat belajar angka dan huruf, alat permainan seperti perosotan, Tv yang digunakan utuk memutar film/lagu anak, boneka, sepeda roda tiga, bahan dan alat tulis menulis.

Fasilitas tersebut seperti puzzle sebaiknya di sediakan oleh Dinas Perpustakaan dan Kearsipan Kabupaten Sijunjung yang mana peralatan bermain anak tersebut sangat membantu untuk meningkatkan kunjungan terhadap anak serta dapat membantu meningkatkan minat baca anak sejak dini. 


\section{Keterbatasan tenaga kerja dan pustakawan}

Keterbatasan yang dimaksud yaitu pustakawan yang ada di perpustakaan sudah tidak mampu untuk bekerja banyak sehingga pustakawan tidak mampu untuk menjalankan dan mengembangkan program untuk layanan anak di perpustakaan.

Selain itu, adapun tenaga kerja ataupun pegawai di bidang struktural perpustakaan yang merupakan orang-orang pindahan dari berbagai dinas yang mana tidak memiliki latar belakang perpustakaan sehingga program yang dirancang oleh pustakawan tidak dapat dijalankan dan dikembangkan dengan maksimal.

\section{Pandangan masyarakat}

Pandangan masyarakat yang dimaksud yaitu bagimana masyarakat melihat perpustakaan umum tersebut. Masyarakat Sijunjung masih beranggapan bahwa perpustakaan hanyalah gudang tempat penyimpanan koleksi atau buku-buku yang usang dan telah lama tidak terpakai. Oleh karena itu masyarakat malas dan tidak mau untuk berkunjung ke perpustakaan.

Dalam hal ini Dinas Perpustakaan dan Kearsipan Kabupaten Sijunjung sangat berperan penting yang mana perpustakaan dapat menciptakan pandangan positif dari masyarakat terhadap perpustakaan yang menganggap perpustakaan tersebut bukan hanya tempat penyimpanan koleksi/gudang saja. Namun perpustakaan pada saat ini yaitu perpustakaan yang dapat memenuhi kebutuhan informasi pemustaka seperti masyarakat baik dari masyarakat dewasa, remaja dan bahkan anak-anak. Selain itu perpustakaan juga sebagai tempat rekreasi bagi anak-anak maupun orang dewasa.

\section{Diskusi dan Kesimpulan}

Berdasarkan hasil wawancara dengan pustakawan dan tenaga kerja di Dinas Perpustakaan dan Kearsipan Kabupaten Sijunjung telah melakukan strategi dalam meningkatkan kunjungan pada layanan anak. Kegiatan yang dilakukan oleh pustakawan yaitu pertama, melakukan berbagai lomba seperti mewarnai, bercerita, dan melukis. Kedua, melakukan kegiatan bimbingan belajar dan storytelling yang dapat menumbuhkan minat baca anak. Ketiga, melakukan kegiatan dengan perpustakaan keliling, kegiatan ini dilakukan dengan berkeliling ke berbagai sekolah yang ada di Kabupaten Sijunjung sehingga akan memunculkan anggapan bahwa 
perpustakaan bukan hanya tempat penyimpanan buku lama saja dan dapat membantu masyarakat dalam mencerdaskan bangsa.

Menurut penulis, sebaiknya Dinas Perpustakaan dan Kearsipan Kabupaten Sijunjung melakukan kerjasama dengan berbagai organisasi ataupun instansi yang mana kerjasama ini dapat membantu dari segi fasilitas yang ada di layanan anak, membantu promosi perpustakaan melalui berbagai organisasi yang bergerak di bidang literasi informasi, dan lain-lain. Selain itu, menurut penulis sebaiknya Dinas Perpustakaan dan Kearsipan melakukan pembenahan secara maksimal di layanan anak dan menjadikan layanan anak sebagai prioritas utama dalam pengembangan perpustakaan.

\section{E. Daftar Pustaka}

Cahyaningtyas, R., \& Iriyani, S. (2015). Perancangan Sistem Informasi Perpustakaan Pada Smp Negeri 3 Tulakan, Kecamatan Tulakan Kabupaten Pacitan . Indonesian Journal on Networking and Security, 15-20.

Lestari, S., \& Nelisa, M. (2015). Peran Pustakawan Dalam Memotivasi Anak Usia Dini Memanfaatkan Layanan Anak Di Badan Perpustakaan Dan Kearsipan Provinsi Sumatera Barat. Jurnal Ilmu Informasi Perpustakaan dan Kearsipan, 24-34.

Moleong, L. J. (2001). Metodologi Penelitian Kualitatif. Bandung: Remaja Rosdakarya.

Rizki, M. (2019). Strategi Kegiatan Mendongeng Pada Layanan Anak Di Dinas Perpustakaan Dan Arsip Provinsi Sumatera Utara. Skripsi, 128.

Sjahrijal-Pamuntjak. (2000). Pedoman Penyelenggaraan Perpustakaan. Jakarta: Djambatan.

Sulistyo-Basuki. (1993). Penghantar Ilmu perpustakaan. Jakarta: Gramedia Pustaka Utama.

Wahyuni, M. (2015). Peran Pustakawan Sebagai Penyedia Informasi. Jurnal Iqra' Volume 09 No.02, 44-45. 